\title{
The Female Preponderance to Cough Hypersensitivity Syndrome: Another Clue Pointing to the Role of TRPV1 in Cough
}

\author{
Kornelis W. Patberg
}

Received: 12 February 2011/Accepted: 3 April 2011/Published online: 21 April 2011

(C) The Author(s) 2011. This article is published with open access at Springerlink.com

In a recently published study by Morice et al. [1] cough hypersensitivity syndrome (CHS) is put forward as a distinct disease entity, an exciting concept. Within their definition, the lion's share of patients referred to a specialized cough clinic would fit the diagnosis of CHS (as assessed by the newly presented Hull Airway Reflux Questionnaire [1]). This single clinical entity includes several phenotypes like rhinitis-dominant CHS or the predominantly Th2 response CHS (also known as cough-variant asthma). However, the hypothesis is that a single precipitant predisposes these patients to cough. The authors speculate that this is a gaseous nonacid reflux that has been undetectable thus far with the currently available techniques.

An alternative (or complementary) predisposing factor one could think of is upregulation of the receptorchannel transient receptor potential vanilloid (TRPV) type 1. Morice et al. have done a vast amount of work exploring the role of this ion channel in chronic cough and so have others [2-4]. This channel has gained popularity as a "cough-mediating receptor" since it triggers afferent nerve activity in response to cough-provoking stimuli, including heat, acid, and certain arachidonic acid derivatives. The channel is also indirectly activated by inflammatory mediators like bradykinin, nerve growth factor, and prostaglandin [5]. Furthermore, TRPV1 expression is increased in chronic coughers and the channel is upregulated in reaction to inflammation $[3,4]$.

From the data presented in Morice et al., I think another clue to the involvement of TRPV1 might be derived. As shown before by others [6,7], the study by Morice et al.

K. W. Patberg $(\bowtie)$

Department of Respiratory Medicine, Academic Medical Center, Meibergdreef 9, 1105 AZ Amsterdam, The Netherlands

e-mail: k.w.patberg@amc.uva.nl shows a female preponderance for developing CHS. Hitherto this female predilection to CHS has not been elucidated. However, the literature offers the ingredients for a plausible hypothesis which is in line with a role for TRPV1 in CHS.

A female predominance for afflictions involving ion channels is not unusual in nature. The influence of sex hormones on ion channels has long been recognized, explaining many pathogenic differences between men and women. For example, women are at greater risk for druginduced cardiac arrhythmias, and the female gender itself is an independent risk factor for sudden death. This is, at least in part, explained by an effect of estrogen on mRNA levels of several potassium and calcium channels (reviewed in [8]). Estrogen also influences TRPV1 activation/sensitization. Although some controversy exists, most studies describe a gain of function. Not surprisingly, most reports on this subject stem from the field of gynaecology and describe the importance of the channel in activating afferent nerve fibers in gynecologic pain. Yan et al. [9] show that in ovariectomized rats TRPV1 becomes important only in activating afferent nerve fibers in response to uterine cervical distension after estrogen replacement therapy. Peng et al. [10] show that the sensitization of TRPV1 as a nociceptive activator of $\mathrm{C}$ fibers in rats is dependent on the estrous cycle. Moreover, they demonstrated that capsaicininduced activation of $\mathrm{C}$ fibers is significantly greater in the proestrus stage (high estradiol, low progesterone) than in the metestrus stage (low estradiol, high progesterone), favoring estradiol over progesterone as a hormonal mediator of TRPV1. Kiasalari et al. [11] identified a population of C-fiber cells that express high levels of TRPV1 and more than $75 \%$ of these cells express estrogen receptor $\alpha$, suggesting a role for estrogen in regulating these cells.

From the above, it is hypothesized that the influence of estrogen on TRPV1 predisposes the female sex to CHS, 
thus explaining the higher prevalence of CHS among women. This association would strengthen the hypothesis that TRPV1 is important in CHS.

Open Access This article is distributed under the terms of the Creative Commons Attribution Noncommercial License which permits any noncommercial use, distribution, and reproduction in any medium, provided the original author(s) and source are credited.

\section{References}

1. Morice AH, Faruqi S, Wright CE, Thompson R, Bland JM (2011) Cough hypersensitivity syndrome: a distinct clinical entity. Lung 189(1):73-79

2. Millqvist E, Ternesten-Hasséus E, Bende M (2008) Inhaled ethanol potentiates the cough response to capsaicin in patients with airway sensory hyperreactivity. Pulm Pharmacol Ther 21(5):794797

3. Mitchell JE, Campbell AP, New NE, Sadofsky LR, Kastelik JA, Mulrennan SA, Compton SJ, Morice AH (2005) Expression and characterization of the intracellular vanilloid receptor (TRPV1) in bronchi from patients with chronic cough. Exp Lung Res 31(3):295-306

4. Groneberg DA, Niimi A, Dinh QT, Cosio B, Hew M, Fischer A, Chung KF (2004) Increased expression of transient receptor potential vanilloid-1 in airway nerves of chronic cough. Am J Respir Crit Care Med 170(12):1276-1280

5. Adcock JJ (2009) TRPV1 receptors in sensitisation of cough and pain reflexes. Pulm Pharmacol Ther 22(2):65-70

6. Kelsall A, Decalmer S, McGuinness K, Woodcock A, Smith JA (2009) Sex differences and predictors of objective cough frequency in chronic cough. Thorax 64(5):393-398

7. Kastelik JA, Thompson RH, Aziz I, Ojoo JC, Redington AE, Morice AH (2002) Sex-related differences in cough reflex sensitivity in patients with chronic cough. Am J Respir Crit Care Med 166(7):961-964

8. Pham TV, Rosen MR (2002) Sex, hormones, and repolarization. Cardiovasc Res 53(3):740-751

9. Yan T, Liu B, Du D, Eisenach JC, Tong C (2007) Estrogen amplifies pain responses to uterine cervical distension in rats by altering transient receptor potential-1 function. Anesth Analg 104(5):1246-1250

10. Peng HY, Huang PC, Liao JM, Tung KC, Lee SD, Cheng CL, Shyu JC, Lai CY, Chen GD, Lin TB (2008) Estrous cycle variation of TRPV1-mediated cross-organ sensitization between uterus and NMDA-dependent pelvic-urethra reflex activity. Am J Physiol Endocrinol Metab 295(3):E559-E568

11. Kiasalari Z, Salehi I, Zhong Y, McMahon SB, Michael-Titus AT, Michael GJ (2010) Identification of perineal sensory neurons activated by innocuous heat. J Comp Neurol 518(2):137-162 